\title{
ОСНОВНІ НАПРЯМИ ЗБАЛАНСОВАНОГО РОЗВИТКУ ІТ-СЕКТОРУ
}

Визначено основні напрями комплексної програми збалансованого розвитку IT-сектору, потребу забезпечення іiі комплексного розвитку та збалансованої і стабільної роботи. З'ясовано, що до програми збалансованого розвитку варто віднести такі напрямки: IT-аутсорсінг; R\&D центри; Стартапи; Е-комерція; IT в державному управлінні; IT-інфраструктура; Кібербезпека. Рекомендовано заходи та механізми коротко- та довготермінового характеру розвитку науково-дослідних центрів $\mathrm{i}$ стартапів України. Визначено ресурси, необхідні для збалансованого і ефективного розвитку цих напрямків та оцінено прогнозовані результати (зростання обсягів бюджетних надходжень, зростання рівня інноваційних продуктів, вдосконалення національної інноваційної системи тощо). Досліджено, що максимальне спрощення процедури відкриття за кордоном певного типу операцій - це обгрунтована потребу повного і прозорого доступу вітчизняних підприємців до міжнародних онлайн торгівельних майданчиків. Досліджено процес удосконалення бізнес-середовища для гравців телекомунікаційного ринку України. Особливу увагу приділено аналізу загрози для України кібергшпигунства у сфері критичної інфраструктури (енергозабезпечення, водопостачання, транспорт).

Ключові слова: заходи; механізми; ІТ-індустрія; інформаційні технології.

Вступ. Розвиток інформаційного простору та інформаційних технологій $є$ конкретним чинником стимулювання економічного зростання, підвищення рівня конкурентоспроможності національної економіки та економічної інтеграції країни.

Основні напрями комплексної програми розвитку IT-сектору України, які забезпечують стратегії розвитку суб'єктів господарювання в умовах загострення конкуренції на внутрішньому та зовнішньому ринках, повинні бути сконцентровані на активізації якісного вдосконалення всіх складових компонентів IT-сектору та поглиблення зв'язків між ними. До складу основних напрямків комплексної програми збалансованого розвитку IT-сектору варто віднести такі: IT-аутсорсінг; R\&D центри; Стартапи; Е-комерція; IT в державному управлінні; IT-інфраструктура; Кібербезпека (Kolomiiets, 2008).

Мета роботи. У сучасних умовах одним із головних каталізаторів динамічного розвитку економічних систем стає сектор високих технологій, як основа інноваційної екосистеми. Постає питання визначення та обгрунтування не тільки основних складових елементів інноваційної екосистеми, але й забезпечення їх комплексного розвитку та збалансованої та стабільної роботи.

Викладення основного матеріалу. На сьогодні ITаутсорсінг $\epsilon$ найвагомішим структурним компонентом та головним рушієм українського IT-сектору. Світовий попит на послуги розроблення програмного забезпечення у найближчій перспективі буде тільки зростати, що зумовлено впливом сучасних технологічних трендів та розвитком стратегій автоматизації великого та середнього бізнесу. Це створює для України досить сприятливі можливості для побудови власної IT-індустрії світового масштабу в сегменті розроблення програмного забезпечення, IT-послуг та консалтингу. У сучасних умовах активне зростання сфери IT-аутсорсінгу здійснює відчутний позитивний макроекономічний вплив на економічний розвиток України, який за умови успішної реалізації обгрунтованої політики підтримки та стимулювання розвитку IT-аутсорсінгу, здатен перетворитися на один із провідних чинників зростання української економіки.

Оперативна та ефективна реалізація спільно органами влади, IT-компаніями та освітньою сферою запропонованого (рис. 1) переліку короткотермінових рекомендованих заходів та механізмів розвитку IT-аутсорсінгу створить сприятливі можливості для вдосконалення двох основних елементів, критично важливих для цієї сфери IT-сектора - загального стану бізнес-середовища та чисельності кваліфікованих IT-спеціалістів. Це дасть змогу зберегти позитивну динаміку зростання обсягу експорту IT-послуг, а за умови успішної реалізації довготермінових заходів - створити міцне підгрунтя для

Інформація про авторів:

Коломієць Олена Георгіївна, канд. екон. наук, інженер, кафедра економіки підприємства.

Email: alenkolom@i.ua; https://orcid.org/0000-0002-0400-4805

Михайловський Василь Іванович, канд. екон. наук, доцент, кафедра економіки підприємства. Email: lavara@i.ua

Наливайко Наталія Ярославівна, канд. екон. наук, доцент, кафедра економіки підприємства.

Email: nalivajko21@gmail.com; https://orcid.org/0000-0003-4310-9367

Цитування за ДСТУ: Коломієць О. Г., Михайловський В. І., Наливайко Н. Я. Основні напрями збалансованого розвитку ІТ-сектору. Науковий вісник НЛтУ України. 2019, т. 29, № 4. С. 53-56.

Citation APA: Kolomiets, O. G., Mikhailovsky, V. I., \& Nalyvaiko, N. Ya. (2019). Main directions of balanced development of the IT sector. Scientific Bulletin of UNFU, 29(4), 53-56. https://doi.org/10.15421/40290411 
підвищення темпів зростання та істотно покращення своїх позицій на світовому IT-ринку (Tretiak, 2006; Asotsiatsiia, 2019; Zhurovskyi, 2015).

Українські спеціалісти, співробітники R\&D центрів міжнародних компаній, задіяні в розробленні найсучасніших інноваційних технологій та нових видів продукції для різних напрямів світової індустрії ІКТ: розроблення комп'ютерних ігор; телекомунікації; електронна торгівля; розроблення програмного забезпечення.
Головними передумовами для зростання кількості $\mathrm{R} \& \mathrm{D}$ центрів міжнародних компаній, а також приходу світових лідерів IT-індустрії (Microsoft, Apple, Google, IBM, Intel), є істотне покращення умов ведення бізнесу, зростання політичної та економічної стабільності, вдосконалення захисту прав інтелектуальної власності відповідно до міжнародних стандартів (рис. 2).

\begin{tabular}{|c|c|c|c|}
\hline \multicolumn{2}{|c|}{ Рекомендовані заходи та механізми } & Ресурси & $\begin{array}{c}\text { Прогнозований } \\
\text { результат }\end{array}$ \\
\hline 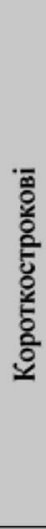 & $\begin{array}{l}\text { - Міжнародна промо-кампанія України як } \\
\text { одного із технологічних лідерів у } \\
\text { світовій IT-індустрії; } \\
\text { - Створення сприятливих умов } \\
\text { оподаткування для IT-сектора шляхом } \\
\text { прийняття відповідного законодавства } \\
\text { або збереження можливості роботи } 3 \\
\text { приватними підприємиями; } \\
\text { - Створення спрощених та прозорих умов } \\
\text { для відкриття нових компаній та } \\
\text { супроводу їх діяльності; } \\
\text { - Розробка порядку оперативного } \\
\text { реагування органів влади на } \\
\text { перевищення повноважень при перевірці } \\
\text { IТ-компаній та заборона на вилучення } \\
\text { технічних засобів. }\end{array}$ & $\begin{array}{l}\text { - Державне } \\
\text { фінансове та } \\
\text { інформаційне } \\
\text { забезпечення; } \\
\text { - Розробка та } \\
\text { прийняття } \\
\text { законодавчих } \\
\text { актів та урядових } \\
\text { постанов; } \\
\text { - Організаційні та } \\
\text { законодавчі; } \\
\text { - Організаційні та } \\
\text { законодавчі. }\end{array}$ & $\begin{array}{l}\text { - Підвищення } \\
\text { позитивного іміджу } \\
\text { українського IT- } \\
\text { сектора та зростання } \\
\text { об'єму експорту IT- } \\
\text { послуг; } \\
\text { • Зростання обсягів } \\
\text { бюджетних } \\
\text { надходжень; } \\
\text { - Зростання кількості } \\
\text { робочих місць у } \\
\text { високотехнологічних } \\
\text { та суміжних сферах; } \\
\text { - Підвищення } \\
\text { привабливості } \\
\text { українського IT- } \\
\text { ринку. }\end{array}$ \\
\hline 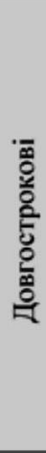 & $\begin{array}{l}\text { - Розробка та прийняття ЗУ "Про } \\
\text { Державну програму розвитку } \\
\text { інформаційно-комунікаційних } \\
\text { технологій в Україні"; } \\
\text { - Поетапна реалізація Цифрового порядку } \\
\text { денного для України; } \\
\text { - Модернізація системи освіти в Україні } \\
\text { відповідно до ринкових потреб; } \\
\text { - Збільшити держзамовлення на IТ- } \\
\text { спеціальності в провідних технічних } \\
\text { ВНЗ країни; } \\
\text { - Введення предмета "Програмування" в } \\
\text { шкільні програми середніх та старших } \\
\text { класів. }\end{array}$ & $\begin{array}{l}\text { - Розробка та } \\
\text { прийняття } \\
\text { законодавчих } \\
\text { актів та урядових } \\
\text { постанов; } \\
\text { - Організаційні та } \\
\text { законодавчі; } \\
\text { - Фінансування та } \\
\text { координація із } \\
\text { Міністерства } \\
\text { освіти та науки } \\
\text { України. }\end{array}$ & $\begin{array}{l}\text { - Стимулювання росту } \\
\text { ІТ-сектора; } \\
\text { - Вдосконалення } \\
\text { національної системи } \\
\text { освіти; } \\
\text { - Зростання } \\
\text { чисельності IT- } \\
\text { спеціалістів. }\end{array}$ \\
\hline
\end{tabular}

Рис. 1. Перелік рекомендованих заходів та механізмів розвитку IT-аутсорсінгу в Україні

\begin{tabular}{|c|c|c|c|}
\hline \multicolumn{2}{|r|}{ Рекомендовані заходи та механізми } & Ресурси & $\begin{array}{c}\text { Прогнозований } \\
\text { результат }\end{array}$ \\
\hline 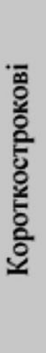 & $\begin{array}{l}\text { - Міжнародна промо-кампанія України як } \\
\text { одного із технологічних лідерів у } \\
\text { світовій IT-індустрії; } \\
\text { - Забезпечення захисту прав } \\
\text { інтелектуальної власності у } \\
\text { відповідності з міжнародними } \\
\text { стандартами; } \\
\text { - Максимальне спрощення процедури } \\
\text { отримання робочих віз для } \\
\text { висококваліфікованих закордонних IT- } \\
\text { спеціалістів; }\end{array}$ & $\begin{array}{l}\text { - Державне } \\
\text { фінансове та } \\
\text { інформаційне } \\
\text { забезпечення; } \\
\text { Організаційні та } \\
\text { законодавчі; }\end{array}$ & $\begin{array}{l}\text { - Підвищення } \\
\text { позитивного іміджу } \\
\text { українського IT- } \\
\text { сектора; } \\
\text { - Зростання рівня } \\
\text { привабливості країни } \\
\text { для розробки } \\
\text { інноваційних } \\
\text { продуктів. }\end{array}$ \\
\hline 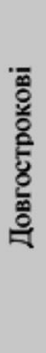 & $\begin{array}{l}\text { - Створення привабливих умов для } \\
\text { міжнародних компаній при відкритті } \\
\text { R\&D центрів та залученні українських } \\
\text { IT-спеціалістів; } \\
\text { - Створення інноваційних парків, } \\
\text { технологічних платформ, бізнес- } \\
\text { інкубаторів та інших компонентів } \\
\text { інноваційної екосистеми; } \\
\text { - Стимулювання створення IT-кластерів та } \\
\text { технопарків на основі державно- } \\
\text { приватного партнерства. }\end{array}$ & $\begin{array}{l}\text { - Розробка та } \\
\text { прийняття } \\
\text { законодавчих } \\
\text { актів та урядових } \\
\text { постанов; } \\
\text { - Організаційні та } \\
\text { законодавчі; }\end{array}$ & $\begin{array}{l}\text { - Зростання кількості } \\
\text { залучених } \\
\text { міжнародних } \\
\text { компаній; } \\
\text { - Вдосконалення } \\
\text { національ ної } \\
\text { інноваційної } \\
\text { системи; } \\
\text { - Збільшення обсягу } \\
\text { податкових } \\
\text { надходжень. }\end{array}$ \\
\hline
\end{tabular}

Рис. 2. Перелік рекомендованих заходів та механізмів розвитку науково-дослідних (R\&D) центрів у Україні 
В довготерміновій перспективі, стимулювання створення IT-кластерів та технопарків на основі державноприватного партнерства разом із спеціальним режимом податкових стимулів та інших привабливих умов при відкритті R\&D центрів, можуть істотно активізувати інтерес міжнародних IT-компаній до України, як локації для розміщення своїх центрів досліджень та розроблення (Tretiak, 2006).

Серед усіх сегментів IT-сектору, технологічні стартапи є особливо чутливі до якості національної IT-екосистеми, оскільки від ії ефективності безпосередньо залежить його життєздатність та можливості розвитку. Зважаючи на те, що в Україні є всі необхідні передумови для створення інновацій та високотехнологічних продуктів, але відсутня ефективно функціонуюча IT- екосистема та великий внутрішній ринок, виникає нагальна потреба у визначенні пріоритетів та оптимальних механізмів розвитку сфери венчурного бізнесу.

Визначення своїх конкурентних переваг, їх правильне використання разом із концентрацією на початкових етапах життя технологічних стартапів, без намагання побудувати копію чужої екосистеми, може допомогти нашій державі перетворитися в потужний інкубатор для нових стартапів, в якому вони будуть проходити свої початкові етапи життя, а для зростання виходити на великі ринки розвинутих країн (США, СС). Така стартапспеціалізація може допомогти Україні стати інноваційно-технологічним хабом, в котрому міжнародні компанії будуть прагнути відкрити свої $\mathrm{R} \& \mathrm{D}$ центри, а не тільки замовляти послуги IT-аутсорсінгу (рис. 3).

\begin{tabular}{|c|c|c|c|}
\hline \multicolumn{2}{|c|}{ Рекомендовані заходи та механізми } & Ресурси & $\begin{array}{c}\text { Прогнозований } \\
\text { результат }\end{array}$ \\
\hline 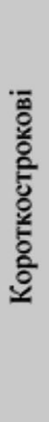 & $\begin{array}{l}\text { Створення та налагодження ефективного } \\
\text { функціонування підприємницькӧ } \\
\text { екосистеми та всіх існуючих інститутів } \\
\text { розвитку; } \\
\text { - Популяризація інноваційного } \\
\text { підприємництва на державному рівні; } \\
\text { Спрощення процедури розширення } \\
\text { бізнесу шляхом придбання чи відкриття } \\
\text { українськими громадянами компанії } \\
\text { закордоном; } \\
\text { Покращення корпоративного управління } \\
\text { та захисту прав міноритарних } \\
\text { інвесторів. }\end{array}$ & $\begin{array}{l}\text { - Організаційні та } \\
\text { законодавчі; } \\
\text { - Державне } \\
\text { фінансове та } \\
\text { інформаційне } \\
\text { забезпечення; } \\
\text { - Законодавчі; }\end{array}$ & $\begin{array}{l}\text { - Зростання кількості } \\
\text { інноваційних } \\
\text { компаній ( в т.ч. } \\
\text { продуктових IT- } \\
\text { компаній) } \\
\text { - Зростання загального } \\
\text { обсягу надходжень } \\
\text { до державного } \\
\text { бюджету; }\end{array}$ \\
\hline 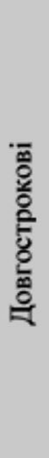 & $\begin{array}{l}\text { - Створення Державної венчурної } \\
\text { компанії з метою спільного } \\
\text { фінансування разом із бізнесом } \\
\text { найкращих інноваційно-технологічних } \\
\text { проектів; } \\
\text { • Створення професійних державно- } \\
\text { приватних венчурних фондів; } \\
\text { • Налагодження ефективної роботи Офісу } \\
\text { високих технологій; } \\
\text { • Грантова підтримка найкращих } \\
\text { інноваційно-технологічних проектів; } \\
\text { • Розвиток інститутів розвитку в } \\
\text { технологічних університетах з метою } \\
\text { комерціалізації їх наукових розробок. }\end{array}$ & $\begin{array}{l}\text { - Організаційні та } \\
\text { законодавчі; } \\
\text { - Державне } \\
\text { фінансування в } \\
\text { залежності від } \\
\text { національного } \\
\text { пріоритету. }\end{array}$ & $\begin{array}{l}\text { - Зростання кількості } \\
\text { інноваційних } \\
\text { компаній ( в т.ч. } \\
\text { продуктових IT- } \\
\text { компаній); } \\
\text { - Прискорення } \\
\text { зростання } \\
\text { високотехнологічних } \\
\text { галузей економіки; } \\
\text { - Зростання загального } \\
\text { обсягу надходжень } \\
\text { до державного } \\
\text { бюджету. }\end{array}$ \\
\hline
\end{tabular}

Рис. 3. Перелік рекомендованих заходів та механізмів розвитку стартапів у Україні

На сьогодні Україна не входить до переліку визначених країн для реєстрації на одному з провідних світових торгівельних майданчиків - Amazon, робота на еВау передбачає наявність у підприємця аккаунту в платіжній системі PayPal, яка в Україні наразі не підтримує функцію виведення коштів. Забезпечення повного доступу українських підприємців до міжнародних онлайн-торгівельних майданчиків і успішного прийому платежів від закордонних покупців можливе завдяки максимальному спрощенню процедури відкриття рахунків за кордоном для цього типу операцій, а також спрощенню видачі ліцензій на емісію електронних грошей та їх адміністрування для міжнародних платіжних систем (Asotsiatsiia, 2019; Zhurovskyi, 2015).

Окремої уваги потребує процес удосконалення бізнес-середовища для всіх гравців телекомунікаційного ринку України, спрощення процедури отримання дозволів та ліцензій, забезпечення рівних умов доступу до телекомунікаційної інфраструктури (кабельної каналізації електрозв'язку, об'єктів інфраструктури будівництва, транспорту та електроенергетики), а також розроб- ку механізмів захисту критично важливих компонентів IT-інфраструктури, які виключають можливість примусового вимкнення мереж та вилучення серверного обладнання (Asotsiatsiia, 2019; Zhurovskyi, 2015).

У цьому випадку, якість бізнес-середовища - один із ключових компонентів, який або стимулює активний розвиток галузі завдяки постійному зростанню обсягів інвестицій, або стримує, негативно впливаючи на динаміку та ефективність процесу розбудови IT-інфраструктури.

Автоматизація сервісних функцій державних і місцевих органів влади передбачає або стабільно значне державне фінансування, або залучення до реалізації цього проекту приватного капіталу. У сучасних умовах світовим трендом у сфері електронного урядування $\epsilon$ відповідальний аутсорсінг та зважена капіталізація. Ключовим рішенням для впорядкування, інтенсифікації та активного зростання кількості та якості онлайн-послуг у сфері державного управління в Україні є впровадження сучасних моделей державно-приватного партнерства у сфері електронного урядування. 
Як свідчить досвід електронного урядування та впровадження IT у сферу державного управління в Україні, одним із найбільш реалістичних сценаріїв розвитку цієї сфери є залучення провідних українських та іноземних IT-спеціалістів, зацікавлених у реалізації процесу автоматизації основних напрямків державного управління та регуляторної діяльності, до розроблення, впровадження та подальшої підтримки нових IT-послуг у сфері державного управління.

Інтенсивне поширення IT-технологій у більшості сфер суспільної життедіяльності в сучасних умовах, окрім численних позитивних ефектів, також супроводжується підвищенням рівня ризику та зростанням кількості загроз у процесі їх функціонування. Почастішали випадки злочинних дій під час здійснення банківських операцій та покупок через мережу Інтернет, від яких потерпають як приватні особи, так і бізнесструктури в Україні. Разом з тим, у сучасних умовах особливо актуальною для української держави є загроза кібершпіонажу в сфері критичної інфраструктури (сфери енергозабезпечення, водопостачання, транспорту, банківського та телекомунікаційного секторів) та державної безпеки. У таких умовах особливо важливою стає здатність держави ефективно протистояти всім кіберзагрозам, наявність дієвого механізму інформування суспільства про наявні ризики, а також підтримка бізнесу в процесі розроблення, впровадження та практичного використання безпечних IT-технологій (Asotsiatsiia, 2019; Zhurovskyi, 2015).

Висновки. Послідовна реалізація комплексної програми підтримки розвитку IT-кластерів у Україні, розробленої на основі запропонованої концепції, здатна за- безпечити досягнення таких результатів: перетворення найактивніших IT-кластерів у інноваційно-технологічні хаби національного рівня, а в перспективі - досягнення лідерських позицій у регіоні Центральної та Східної Європи; злагоджене функціонування національної інноваційної екосистеми України, що характеризується ефективною взаємодією всіх іiі компонентів на шляху від креативної ідеї до IPO його компанії чи продажу стратегічному інвестору; еволюція українського IT-сектору від домінуючої аутсорсінгової моделі до продуктової (створення нової інтелектуальної власності та тиражування готових продуктів на міжнародних ринках).

\section{Перелік використаних джерел}

Asotsiatsiia. (2019). Ukrainska Asotsiatsiia Investytsiinoho Biznesu UAIB: Kvartalni ta richni ohliady rynku ISI v Ukraini. Retrieved from: http://www.uaib.com.ua/analituaib/publ ici quart.html. [In Ukrainian].

Kolomiiets, O. H. (2008). Ekonomichni osnovy upravlinnia investuvanniam v potochnu diialnist pidpryiemstva. Sotsialno-ekonomichni naslidky ta stratehiia reformuvannia ekonomiky Ukrainy: Materials of the inter-university scientific-practical conference of students and post-graduate students, Lviv April 15, 2008. (pp. 426428) Lviv: LKA publishing house. [In Ukrainian].

Tretiak, V. P. (2006). Klastery predpriiatii: puti sozdaniia i rezultativnost funktcionirovaniia. Moscow: Avgust Borg, 132 p. [In Russian].

Zhurovskyi, M. Z. (2015). Forsait ekonomiky Ukrainy: serednostrokovyi (2015-2020 roky) i dovhostrokovyi (2020-2030 roky) chasovi horyzonty. Mizhnarodna rada z nauky (ICSU); Komitet iz systemnoho analizu pry Prezydii NAN Ukrainy. Kyiv: NTUU "KPI", 136 p. [In Ukrainian].

O. G. Kolomiets, V. I. Mikhailovsky, N. Ya. Nalyvaiko Ukrainian National Forestry University, Lviv, Ukraine

\section{MAIN DIRECTIONS OF BALANCED DEVELOPMENT OF THE IT SECTOR}

Main focus area of the balanced development program of the IT-sector in Ukraine is investigated. Suggestions about the improvement of support mechanisms of IT-clusters development in the process of innovative ecosystem formed on the basis of justification substantiation of component-based structure of integrated development program of the IT-sector in Ukraine are made. Integrated development program is to include the development of information space and information technologies as it is a powerful factor of economic growth promotion, increasing of the level of competitive ability of the economy and economic integration of the country. Measures and mechanisms of the development of IT-outsourcing, R\&D centers, Start-ups, ecommerce, IT in public administration, IT-infrastructure, cyber security, research centres and start-ups of Ukraine are recommended. There is a justification of necessary resources for the development of these directions such as organizational and legislative ones, and public financing. Some results of events are predicted to be as follows: raise of public image of Ukrainian IT-sector, increase of tax revenue and the number of innovative companies. The shortcomings of development of E-companies, IT-infrastructure and cybersecurity are analysed. The ways of business-environment improvement are determined to be such as development of the telecommunications market of Ukraine - simplification of licenses and permits receipt, provision of equal conditions of access to the telecommunications infrastructure; assuring the access to the international online trading facilities - simplification of setting up the accounts abroad and issuance of a license for e-money emission. There is an estimation of the influence and threats of cyber espionage in the field of critical infrastructure - power supply, water supply and banking sector. It is determined that the balanced development of the ITsector in Ukraine will provide the transformation of the most active IT-clusters into the innovative and technological hubs of the national market.

Keywords: measures; mechanisms; IT-industry; information technologies. 